\title{
BOGDÁNY GYULA
}

\section{Az emberölési ügyek nyomozási hibáiról és a szerencse jelentőségéről}

„A rendör jól ismeri a tevékenységét szabályozó elöirásokat, munkáját lelkiismeretesen, magas színvonalon, törvényesen, szakszerüen, hatékonyan végzi. Böviti szakmai ismereteit, fejleszti képességeit. Az elkövetett hibák elemzésével mindent megtesz azért, hogy azok ne ismétlódjenek meg. "'

A rangos hazai történelmi folyóirat közelmúltban megjelent tematikus lapszáma a Mi lett volna, ha?, eleddig szakmaiatlannak tünő kérdés köré rendezte neves kutatóknak a magyar történelem néhány sorsfordító elágazása lehetőségéről alkotott véleményét. ${ }^{2}$ Tekintve, hogy mind a történettudomány, mind a kriminalisztika a saját, de sok szempontból hasonló módszertanával, egyazon célt, a múlt minél pontosabb megismerését kutatja, érdemes áttekinteni, hogy a jogilag releváns tények jogi érdekböl és jogi keretek között történő megismerési folyamatára, a nyomozásra milyen hatással lehet bizonyos változók megléte vagy hiánya. Témánkat a legősibb, a legtöbbet kutatott deliktum, az emberölés nyomozásában felvetődő véletlenszerü kedvező események, az igyekezet ellenére bekövetkező hibák hatásaira és utóbbiak kivédési lehetőségeire összpontosítjuk, és döntően Bács-Kiskun megyei jogesetekkel támasztjuk alá.

A bünözés összességében az erőszakos bünözés csekély hányadot alkot, de a szubjektív biztonságérzetre gyakorolt kedvezőtlen hatásával jelentősen befolyásolja a közállapotok megítélését. Különösen a fejlett országokban, ahol az erőszakos bünözéssel szemben alacsony a társadalom toleranciaszintje. ${ }^{3}$ Kimagasló társadalomra veszélyességük, tárgyi súlyuk folytán a legkirí-

\footnotetext{
1 A Rendőri Hivatás Etikai Kódexe. 8. A munka minőségéről. http://www.police.hu/a-rendorsegrol/testulet/altalanosan/a-rendori-hivatas-etikai-kodexe

2 Rubicon, 2018/10.

3 Az előző és a következő évek adataihoz viszonyítva Anders Breivik 2011-ben, az oslói kormányzati negyedben és Utoya szigetén, robbantással és löfegyverrel elkövetett, összetett cselekménye a sértettek számát figyelembe véve megnégyszerezte a Norvégiában történt emberölések számát. https://ec.europa.eu/eurostat/statistics-explained/index.php?title=File:Homicides_recorded_by_the police,_2002\%E2\%80\%9312_YB14.png
} 
vóbb erőszakos büncselekmények, az emberölések nyomozásai jelentős szervezeti nyomás és fokozott társadalmi érdeklődés mellett zajlanak. ${ }^{4}$

Az általános nyomozó hatósági jogkört gyakorló rendőrség szervezete részéről a kitüntetett figyelem nem csupán a követelménytámasztásban, de arányos eszköz- és erőkoncentráció megteremtésében jelenik meg. A közvéleményt a média aktivitása tartja éberen, e nyomás a nyomozó hatóság irányába a pozitív hírek igényével hivatkozik a jogos - de nem csekély mértékben manipulált - társadalmi érdekre ${ }^{5}$, miközben a helyszínelö típusú sorozatok vagy a bulvárlapok bünügyi rovatai révén kéretlen álszakmai kiképzésben is részesíti a nézőket/olvasókat. ${ }^{6}$

A sértettek száma, személye (például közismert személyiség vagy hozzátartozója, gyermek vagy családanya, rendvédelmi szerv vagy kisebbség tagja), az esetek gyakorisága (például azonos településen vagy sorozatba illően), az elkövetés körülményei (például nyilvános helyen vagy brutalitással), esetleg e tényezők együttesen olyan elvárást támasztanak a nyomozó hatóság a gyors és sikeres munkája vonatkozásában, ami rendkívüli összpontosítást igényel a nyomozás irányítóitól és az abban részt vevőktől.

\section{A nyomozásokban esett hibák típusai, jelentőségük, felismerésük és kivédésük néhány lehetséges módja}

Az emberölési esetek többségében - hiszen az elkövető kézre kerítése halaszthatatlan - a nyomozás forrónyomos felderítéssel (régebbi terminológia szerint forrónyomon üldözéssel) kezdődik. Ennek célja az elkövető kilétének megállapítása, elfogása, a személyi és a tárgyi bizonyítékok felkutatása, lefoglalása, valamint a felderítéshez és a sikeres bizonyításhoz szükséges lényegi információk mihamarabbi beszerzése. ${ }^{7}$

\footnotetext{
4 Sárkány István: Az erőszakos bünözés és a terrorizmus azonos és eltérő kriminológiai jellemzőinek vázlatos áttekintése. Belügyi Szemle, 2018/3., 132-133. o.; Bakóczi Antal - Sárkány István: Erőszak a bünözésben. BM Kiadó, Budapest, 2001, 133-135. o.

5 Korinek László: A bűnözés visszatükröződése. Látens bűnözés, bünözésábrázolás, félelem a bűnözéstől. In: Gönczöl Katalin - Korinek László - Lévai Miklós (szerk.): Kriminológiai ismeretek - Bünözés - Bünözéskontroll. Corvina Kiadó, Budapest, 1996, 82-83. o.

6 Petrétei Dávid - Angyal Miklós: Hol tart ma a kriminalisztika ontogenezise? Magyar Jog, 2018/1., 51-57. o.

https://www.researchgate.net/profile/David_Petretei/publication/323385105_Hol_tart_ma_a_kriminalisztika_ontogenezise/links/5a91 f0940f7e9ba4296db3f7/Hol-tart-ma-a-kriminalisztika-ontogenezise.pdf

7 Bócz Endre (szerk.): Kriminalisztika I-II. BM Duna Palota és Kiadó, Budapest, 2004, 1110-1011. o.
} 
A forrónyomos felderítés nyomozásszervezési modellje eltér a klasszikus, vonalszerú, teljesítési időkkel szakaszolt, gyarapodó és rendezett adatokkal operáló nyomozási modelltől. Az eltérés döntően abban mutatkozik meg, hogy a nyomozásban részt vevők teljes köréhez rövid idő alatt nagy mennyiségü új adat, információ érkezik, ezáltal lerövidül az információk továbbítására, feldolgozására, elemzésére, értékelésére rendelkezésre álló idő, miközben - szintén a teljes állományra vonatkozóan - megnövekszik a döntéshozatali felelősség.

Megfelelő vezetői koncepció esetén a beosztottak is részesei ennek a folyamatnak. Gondoljunk az ügyeleti szolgálat, a helyszínbiztosítók, a szemlebizottság tagjai, az adatgyüjtők, a kihallgatásokat folytatók, a digitális adatok beszerzését és értékelését végzők, a közterületi vagy a körzeti megbízotti szolgálat tagjainak az előttük keletkező, az általuk beszerzett vagy hozzájuk beérkező adatok relevancia szerinti értékelő tevékenységére és a rögzítésről, továbbításról hozott döntéshozatali felelősségére.

A nyomozás irányítóját a szakmai tapasztalata és ismeretei, valamint hangsúlyosan - az intuitív képességei teszik alkalmassá arra, hogy az adott időben meglévő adatok alapján a siker felé irányuló, megfelelő döntést meghozza.

Ezek a döntések kisebb részben jogi vagy adminisztratív természetủek (például védő kirendelése, ügyészség értesítése, elektronikus irat jóváhagyása, aláírása, továbbítása), döntően azonban kriminalisztikai jellegüek.

Amíg azonban az adminisztráció területén elkövetett hibák, hiányosságok (például az ügy kettős iktatása vagy a hozzátartozó értesítéséről szóló feljegyzés elmaradása) nem vagy szinte alig járnak a nyomozás sikere szempontjából káros következménnyel, és könnyen korrigálhatók, addig a törvényesség és hitelesség körében elkövetett hibák (például a hamis szakvéleményadással, a tanúzási akadályokkal kapcsolatos helytelen vagy hiányos figyelmeztetések, vagy a bünjelek megőrzési láncának megszakadása) nem kizárhatóan, de nagyobb erőfeszítéssel hozhatók helyre.

Egy Balotaszálláson, 2008-ban elkövetett kettős emberölés ügyében gyanúsitott személy egyik - igaz, formális - kihallgatásáról felvett jegyzökönyv az iratok rendezetlen kezelése folytán „elkallódott”, amit az elöadó a Robotzsaru rendszerböl kinyomtatott, nem hitelesitett irattal igyekezett palástolni. A biróság által észlelt hiányosságot jogszerüen nem lehetett pótolnibár az eljárási cselekmény tényét és az ott történteket mind a terhelt, mind a védö elismerte -, a kérdéses eljárási cselekményt a biróság kirekesztette a bizonyitékok köréböl. 
Ugyanebben az ügyben a nagyszámú bünjeltárggyal kapcsolatos kaotikus dokumentálás is veszélyeztette a bizonyitás sikerét, amely a holttesteknek a terhelt általi megsemmisitése, a késleltetett felfedezés és a terhelt kitartó tagadása miatt más szempontból is nehezitett volt.

Az igazi, az ügy sorsát tekintve súlyos, akár végzetes defektusokat kriminalisztikai hibák okozzák. ${ }^{8}$

A krimináltechnika alkalmazásában következhetnek be egyebek között a kriminalisztikai fényképezés (például arányítás elmaradása) problémái, a nyomkutatás, -előhívás, -rögzítés módszerének helytelen megválasztása (például DNS-roncsoló anyag daktiloszkópiai célú felületi felvitele, légáramlatban megkísérelt mikroanyagmaradvány-kutatás, vagy a nyomkövetö kutya vezetőszára okozta lábbelinyom-megsemmisülés), valamint - kiemelten - a bünjelek szakszerütlen csomagolása (például rothadás, párolgás, alakvesztés) és a nyomszennyeződés, -kereszteződés (kontamináció)!

A 2000-es évek második felében, M. községben elkövetett, felderitetlen emberölés ügyében, az elkövetö által használt kézmosó szivacs nyirkosan került át nem szellözö csomagolásba, a szakértőhöz már berothadt, DNS-vizsgálatra alkalmatlan állapotban érkezett, ezáltal fontos bizonyiték enyészhetett el. ${ }^{9}$

1995-ben, Kecskeméten, a Mária körúton, idős asszonyok sérelmére elkövetett - felderitetlenül maradt - kettös emberölés ügyében ${ }^{10}$ a halottszemlék jegyzökönyvei hiányoztak a 2004-ben felülvizsgált nyomozás iratai közül. A nyomozás egykori résztvevői már a halottszemle végrehajtóit sem tudták megnevezni. Az újabb nyomozási szakaszban megerösödött az a feltételezés, hogy az egyik sértett körme alatt, a genetikai szakértés eredményeként kimutatott férfi-DNS rögzitésére bonctermi szennyezödés révén került sor, ezt vizsgálta később a szakértö.

A 2010-ben, Petöfiszálláson, tanyán élö idős nő sérelmére elkövetett, (2017-ben felderitett!) emberölés nyomozását közvetlenül megelözö közigazgatási hatósági eljárásban folytatott szemlén, a halott közelébe lépö személyek egyike sem viselt a lábán védöeszközt. Az indifferens személyek

8 Tremmel Flórián: Bizonyítékok a büntetőeljárásban. Dialóg Campus Kiadó, Budapest-Pécs, 2006, 87. o. 9 A DNS-minták szakszerü biztosításáról és ennek jelentőségéről lásd Sótonyi Péter (szerk.): Igazságügyi orvostan. Semmelweis Kiadó, Budapest, 2011, 316-319. o.

10 Hardi Péter: Rejtőzködő gyilkosok. Geopen Könyvkiadó, Budapest, 2009, 240-348. o. 
nyomainak kizárása után az egyébként jó nyomhordozó felületen nem maradt az elkövetönek tulajdonitható lábbelinyom. Ugyanitt, a közigazgatási eljárásban müködö szemlebizottság vezetöjének ujjnyomatát sikerült rögziteni a bünügyi szemle során, a lakás belsö helyiségének ajtótokján.

Általában az előzőeknél később éreztetik hatásukat a nyomozások taktikai melléfogásai. Ezek a hibák és lehetséges következményeik okai csoportosíthatók az eljárási cselekmények végrehajtási szabálytalanságai és a szabályosan megszerzett adatok differenciálatlan értékelése szerint is ${ }^{11}$, mi itt inkább az egyéni vagy csoportos feladat-végrehajtás során történt bekövetkezésük szerint teszünk különbséget. Mindkét kosárból egy-egy eljárási momentumot említünk példaként.

Igen gyakori hiba, hogy akár a tanú, akár a gyanúsított kihallgatásával összefüggésben nem történik meg a kihallgató részéről az eljárási cselekmény technikai és taktikai előkészítése. A kihallgatás arra alkalmatlan, nyitott, mások által folyamatosan használt helyiségben, ,átjáróházban” vagy éppen a kihallgatott nonverbális megnyilvánulásainak megfigyelésére, a kihallgatási tér megteremtésére lehetetlen, bútorokkal zsúfolt, rosszul megvilágított helyiségben történik.

A kihallgatási szituáció jelentőségének kisebbítése nem kétséges, hogy magának a vallomásnak a bizonyítékértékét is előrevetíti. A hiányos vagy téves tartalmú tanúvallomásokon túl ilyen helyzetben a gyanúsított is csekély késztetést érez a valóságközeli nyilatkozata megtételére, ha a kihallgató részéről - még a felkészülésben is - érdektelenséget tapasztal. (E vonatkozásban a közelmúltban saját felmérésünk jelentős eltérést mutatott ki a megyeszékhelyi rendőrkapitányság ügyeleti idejében felvett gyanúsítottkihallgatásaiban, a vallomás megtagadása javára.)

2006-ban, Kiskörösön, egy tizenöt éves lány megölése ügyében, a rövid idö alatt elfogott gyanúsitott elsö kihallgatásán tett, hiányos és ellentmondásokkal tüzdelt vallomásának jegyzökönyve - a beismerési hajlandóság ellenére-mentes volt a pontositó, ellenörzö kérdésektöl. A férfi a vallomásának lényegét a késöbbiekben is fenntartotta, egészen addig, amig bebizonyosodott, hogy a sértett ruháján talált vér nem töle vagy a sértettöl származik. A bíróság bizonyitottság hiányában jogerösen felmentette. Miután újabb szakértöi vizsgálat eredményeként megállapitották, hogy a vér a felmentett

11 Fenyvesi Csaba: A kriminalisztika tendenciái. Dialóg Campus Kiadó, Budapest, 2017, 169-191. o. 
személy - addig eljárás alá nem vont, neki bünsegélyt nyújtó - társáé, perújitási nyomozásban tisztázódott a teljes tényállás, és a két férfi példás büntetést kapott.

Az elsö nyomozással kapcsolatban tanulsággal szolgált továbbá annak vizsgálata, hogy a genetikai szakvélemény beérkezése elött indokolt volt-e befejezni a nyomozást és vádat emelni a terhelt ellen. A szakaszolt büntetöeljárásban nem elhanyagolható az ügyész tevékenységének megitélése sem. A kihallgató személyének helytelen megválasztása mellett a nyomozás sikere ellen hatott az a parancsnoki döntés is, hogy a nyomok gyors megsemmisülésének veszélyét magában hordozó helyszinen, a homokos talajú szölöültetvényen végrehajtott szemle vezetését egy e feladatában kezdö, söt bünügyekkel körözési elöadóként alig érintkezö bizottságvezetöre bizták, aki ezután számos, a bizonyitásra nézvést kifejezetten súlyos szakmai hibát követett el (lábnyomcsapások téves és hiányos leirása, ásónyom leirásának hiánya). Nem tünt célszerünek az sem, hogy a terhelt elfogását a bünügyi vezetök hajtották végre, hiszen az intézkedésük dokumentálása nem az irányitói munka része.

1999-ben, Kecskeméten, egy kiskunfélegyházi cukrászlány sérelmére elkövetett emberölés ügyében ${ }^{22}$ 2015-ben(!) felderitett budapesti illetöségü, visszaesö bünözö férfi elsö érdemi, de a cselekményt tagadó tartalmú vallomásában általánosságban csupán a kérdéses idöszakban való Kecskeméten tartózkodását, nökkel ismerkedö, csavargó életvitelét ismerte el. A kihallgató nem szorgalmazta a részletezést, az azonositható adatok felszinre hozatalát, ezekre pedig a nagy idömúlás miatt égetö szüksége volt a nyomozásnak.

Parancsnoki döntésre a kihallgatás vezetését más elöadó vette át. Az általa konfliktusossá tett kihallgatási helyzetben a gyanúsitott az emlékezetének halványulására hivatkozva kitért minden, a vallomásának ellenörizhetöségére feltett kérdés elöl. E körülményt késöbb a biróság a védekezési taktikája részeként, az utolsó szó jogán történt beismerése ellenére, a terhére értékelte.

Súlyos taktikai hibaforrások vetődhetnek fel az információk gyors és minél teljesebb körü beszerzésére irányuló klasszikus módszer, a területi adatgyüj12 Bogdány Gyula: Emberölések utófelderítésének tapasztalatai Bács-Kiskun megyében. Belügyi Szem-
le, 2017/3., 6-7. o. 
tés körül. Ez a jelentős tervezést, szervezést és élőerőt igénylő nyomozási tevékenység akkor teljesíti célját, ha a végrehajtásban részt vevők a kellő (de a szükséges mértékben szürt!) információt megkapják a büncselekmény alapadatairól, az azokat kiegészítő, azokkal kapcsolatos vagy az ügy szempontjából lényeges adatok beszerzésének okáról, előrevetített jelentőségéről, más adatokkal egyeztethetőségéről (például milyen eseményre, időszakra, személyekre, jármüvekre, tárgyakra vonatkozzék a kérdezés).

Esetenként eligazítást kell adni az állománynak arról is, hogy az adatgyüjtés célját nyíltan, leplezetten vagy legenda alkalmazásával, esetleg demonstratívan hajtsa végre. Szigorúan kerülendő, hogy a kérdezők kikérdezésére kerüljön sor (természetesen ennek ellenpéldájának alkalmazására egy más taktika alapján, tudatosan kerülhet sor).

2011-ben, Mélykúton, aggkorú cipész sérelmére, a lakásában elkövetett emberölés ügyében a négy hónappal késöbb felderitett két elkövetö elmondta, hogy a helyszinre egy helyi kocsmából indultak, ahol elözöleg italozás közben állapodtak meg a közös elkövetésben.

A büncselekménynek a másnap történö felfedezése után, a nyilvános helyeken végrehajtott adatgyüjtéskor az érintett kocsmáros - mivel a szokványos vendégekre nem irányult a kérdésfeltevés - közölte, hogy elözö este idegenek nem jártak ott.

Hiba, hogy az adatgyüjtésről készült jelentések (a szükséges azonnali szóbeli jelentéstételen túl) dokumentálására nem a kellő tartalommal kerül sor és így elvész, de legalábbis elkallódik a „behozott” információ (Ki mondta?, Miért mondta?). Ennek kivédése az adatgyüjtések közben esetleges szóbeli, de a befejezésekor mindenképpen írásbeli jelentéstételek befogadásával és előzetes értékelésével lehetséges. Nagyobb méretủ adatgyüjtést csoportok kialakításával kell megszervezni, a csoportvezető irányító felelősségének hangsúlyozásával. A beérkező információkat ő értékeli, rendezi és továbbítja az adatgyüjtés egészéért felelős személynek.

Az adatgyüjtés céljaként a terület és az ott élő vagy tartózkodó személyek körének teljes lefedettségét kell kitüzni.

Még emberölési ügyekben is előfordul a területi adatgyüjtések (akár többszöri) visszatérővé és teljeskörüvé tételének elmaradása. Kikopni látszik a gyakorlatból a releváns helyeken, területeken a tanúkutatás, elkövetői útvonal vagy akár a környezeti viszonyok (láthatóság, hallhatóság, forgalom, időjárási és fényviszonyok stb.) ellenőrzése céljából a következő napokban vagy 
a hét ugyanazon napján, a cselekmény napszakában, órájában végrehajtandó, „valós idejü", visszatérő adatgyüjtés.

Az adatgyüjtés idejének, területének, aktív (végrehajtó) és passzív (kikérdezett) személyi körének részletes, térképes, táblázatos dokumentálása elengedhetetlen a tervszerü nyomozásszervezés során, hiszen ezzel kontrollálható, hogy egy később lényegessé váló adat mikor, hol, milyen forrásból eredt, hogyan illeszkedik más adatokhoz vagy - akár gyanúokot ${ }^{13}$ is keletkeztetve miként tér el azoktól, felvetve az önmagában álló adat ${ }^{14}$ kérdését.

A 2000-es évek második felében, L. községben, idös férfi sérelmére elkövetett, felderitetlenül maradt emberölés nyomozásában elmaradt a visszatérö területi adatgyüjtés. Bár egyszer, felületesen kikérdezték, mégis csak három év múltán, más adatok alapján került fontos tanú szerepkörbe és történt meg a kihallgatása annak a személynek, aki a sértett közvetlen szomszédjaként az elkövetés elött beszélt két, gyanús kinézetü, a sértett traktora felöl érdeklödö, idegen férfival. E vallomáson kivül más adat nem vetödött fel a lehetséges elkövetők számára, nemére, korára, személyleirására, és a vallomás tartalmának más forrásból történö ellenörzésére az időmúlás miatt sem volt mód.

A hiányosságból hibává érett negatívum okára a nyomozás kezdeti szakaszában még talán magyarázatként lehetett felhozni, hogy a megyei nyomozó szervet abban az idöszakban, ritkán tapasztalt, nagymértékü terhelés érte: bö egy hónap alatt négy emberölésre kellett reagálnia, ezek közül három ismeretlen tettes ellen indult, két-, söt háromsértettes deliktum miatt. Azonban a nyomozás későbbi szakaszában sem történt intézkedés az adatgyüjtés teljessé tételére.

2000-ben, Baján, kerékpározás közben eltünt, és azóta is keresett, tizenegy éves fiúgyermek ügyében ${ }^{15}$ az aggódó szülö bejelentése után órákkal reagált érdemben a helyi rendörség, az adatgyüjtés csak napok alatt vált kiteljesedetté, de akkor is jobbára az eltünt gyerek kapcsolatrendszerére irányult. A területi adatgyüjtés és az ehhez kapcsolódó terepkutatás hiányosságai miatt a gyermek elhagyott kerékpárja csak négy hónap múlva került elö, holott a bejelentö azt már egy hónappal korábban látta a gyermek feltételezett útvonalához közel.

\footnotetext{
13 Tremmel Flórián: i. m. 111., 115. o.

14 Dobos János - Kovács Gyula: Kis nyomozástan. Dr. Kovács Gyula magánkiadása, 2008, 58-59. o.

15 Hardi Péter: i. m. 24-32. o.
} 
A cukrászlány megölése ügyében, a nyomozás első napján, este, a vasútállomáson, a sértett által hazautazásra általában igénybe vett járat indulásakor végrehajtott adatgyüjtésen vált ismertté az a tanú, aki ebben a kérdésben, erre a helyre vonatkozóan egyedüliként, részletes és helytálló leirást adott az elözö este a vonatra váró, általa ismert késöbbi sértettröl. Vallomása nehezen volt egyeztethetö azzal a ténnyel, hogy a sértett holttestét ugyanezen vasútvonal mentén, de két kilométerrel távolabb fedezték fel, másnap reggel. Az elkövetö két évtizeddel késöbbi ismertté válása, az idöszakhoz és helyhez kapcsolása révén volt megalapozottan volt feltehetö, hogy a sértettet a vasútállomásról csalta el, majd kényszeritette eröszakkal az ellene szexuális aktussal összefüggésben elkövetett emberölés helyszinére.

A szemtanú által közölt, addig önmagában álló adat magyarázatot kapott és helyesnek bizonyult.

A 2014-ben, Kunszálláson, egy belga házaspár sérelmére elkövetett, eleddig felderitetlen emberölés nyomozásában a kiterjedt tanyavilágú két település kül-és belterületét három alkalommal vonta - a teljes területet, a teljes lakosságot lefedö, a cselekmény utáni napokban, majd egy hónappal, illetve egy évvel később visszatéröen végrehajtott - adatgyüjtés alá a nyomozást végzö megyei bünügyi osztály irányitásával a helyi és területi szervek állománya.

Következtetésként leszögezzük, hogy - hatásában természetesen túlzón, de folyamatában hasonlóan a légi katasztrófák okaihoz - az emberölés nyomozásában esett vagy ejtett hibák többes előfordulásának kell bekövetkeznie, hogy egy ügy (tett és tettes) sikeres felderítése meghiúsuljon. Mindamellett - ebben eltérve a katasztrófák eredményétől - elismerve az emberölések utófelderítéséhez a Kovács Lajos és munkatársai által kialakított módszertant, állítjuk, hogy a mégoly reménytelennek tünő ügyek késői felderítésére is akad némi esély. ${ }^{16}$

\section{Hiba és/vagy szerencse a nyomozásban}

Az emberölések nyomozása különleges módszertan alkalmazását igényli. Olyat, amely más büncselekménytípusok bevált felderítési, bizonyítási metó-

\footnotetext{
16 Kovács Lajos: Az emberölések utólagos felderítésének helyzete és tapasztalatai Magyarországon. Belügyi Szemle, 2005/1., 3-12. o.; Kovács Lajos: A halálnak élve. Korona Kiadó, Budapest, 2003, $197-$ 198. o.
} 
dusainak összességéből táplálkozó ajánlásokká formálódott, mindamellett mint ahogy nincs két, minden elemében azonos ügy - a megfelelő ügytípusra a megfelelő ajánlástípust kell alkalmazni. A kiválasztást azonban megelőzi és meg kell hogy előzze egy szélesebb mérlegelés, az elkövetés okának és módjának igen tág értelmezésben történő vizsgálata. Az így felállított lehetséges forgatókönyvek verziók formájában számos, egymással párhuzamosan futó felderítési ajánlástípus alkalmazását, figyelembevételét teszik indokolttá.

Ebben a bonyolult és az irányítást végző vezető részéről jókora felkészültséget, alapos rátermettséget igénylő szellemi (és tegyük hozzá, gyakran fizikai) tevékenységben a verziókban gondolkodás és az azok szerinti cselekvés természetszerüleg magában hordozza a hangsúlyok differenciáltságát.

2015-ben, Szalkszentmártonban, a szomszédja tanyáján fejlövés ért egy férfit. Sérülésének jellege csak a kórházi vizsgálat során vált ismertté. Életének megmentéséhez jelentös mértékben hozzájárult a szomszéd általi orvoshoz szállitás. A nyomozás számos verzió alapján indult meg, figyelemmel arra, hogy egyforma eséllyel bármelyik lehetett volna helyes. Ennek keretében megtörtént a segitö szomszéd kezeinek lötényezők biztositása céljából történö letapogatása, miközben az eset idején rajta lévö ruházatának lefoglalására csak napokkal késöbb került sor. Csakúgy késve intézkedtünk a sértett lakásán müködö kamerafelvételek lefoglalására, igy addigra a kérdéses idöszakra vonatkozó, a személyek mozgását láttató képanyag nagyrészt törlödött.

Teljes körben kihallgattuk viszont a tanyatulajdonos által sugallt, „orvvadászverzió" tisztázására az összes környéken lakót és a területen vadgazdálkodást végzöket, akik ezt az elképzelést nem tudták megerösiteni. Az elkövetöi körböl kizártuk továbbá azt a körözött és elfogott személyt, aki a cselekmény idején váratlanul (és mint bebizonyosodott, véletlenül) bukkant fel a helyszin közelében.

A virradatkor végrehajtott helyszini szemlén lefoglalt, vélhetöen az elkövetô által óvatlanul elhagyott egész löszer típusában megegyezett a sértett fejéböl kioperált löszermagéval.

A számos különlegességet hordozó ügy bizonyithatósága, a megjelölt eljárási cselekmények kezdeti késedelmessége ellenére, nem csorbult: az emberölés miatt egykoron elitélt szomszéd bünösségének kimondásához (a sértetti emlékezet, a fegyver és a terhelti beismerés hiányában is!) elegendö bizonyiték állt a biróság rendelkezésére. 
Az utóbbi jogeset erősíti állításunkat, hogy a nyomozásban elkövetett hiba és szerencse kéz a kézben jár. Mindkettő jelentősége többnyire a felderítés sikere után válik ismertté. Esetünkben a forrónyomon megkezdett felderítés - némi szerencsével - elérte célját, fény derült az elkövető által uralt kriminális helyzet (hiszen a helyszínt megváltoztatta, az eszközt eltüntette, a tudomásszerzést késleltette, a tanúkat befolyásolta) föbb, a történtek rekonstruálására alkalmas ismérveire.

Vajon a szerencse körébe sorolható-e az, amilyen módon az 1998-ban, Soltvadkerten megölt vállalkozó holtteste 2001-ben elökerült? Mint később bizonyossá vált, a sértett fia, egyben gyilkosa értesitette a rendörséget névtelen levelében a holttest elrejtésének helyéröl, egy pirtói tanyai kútról. A nagy erökkel végzett földmunkák kezdetben eredménytelenek voltak. Késöbb az odaérkezö jegyzö egy közeli, másik, egykori tanyahelyre hívta fel a figyelmet, az ottani kútból valóban elökerült a holttest. Ugyanebben az ügyben elöbb szerencsétlen körülménynek mutatkozott, hogy a levéliráshoz használt írógépet a megjelenésünk elötti órákban az elkövetö kiváltotta a bizományos kereskedötöl (utóbb sem került elö), miközben döntö bizonyitékként az üzlet papirkosarából elökerült a vételkor készitett - az inkriminált gépirással azonositottpróbairás levélpapirja (késöbb másutt egy újabb irás, ugyanazon gépböl). ${ }^{17}$

Nem soroljuk a szerencséhez az 1996-ban, kiskunfélegyházi lakásán megölt homoszexuális vasutas ügyében felderitett két román férfi egyikének, 2015ben, az ujjnyomata alapján, másikának, 2017-ben, a DNS-mintája alapján történt azonositását sem, hiszen mindkét biometrikus adat utólagos adattári bevitelét, hazai és nemzetközi kerestetését tervszerü nyomozási tevékenység elözte meg. ${ }^{18}$

Szerencsés helyzetnek itélhetö meg azonban, hogy az azonositott ujjnyom 2002 óta megmaradt a romániai adatbázisban, holott az egyébként büntetlen elöéletü mintaadó 2007-ben elhunyt. A siker szempontjából ugyancsak pozitiv fordulat volt, hogy a Spanyolországban élö másik elkövetö DNSmintája 2015-ben, egy bagatell-büncselekmény miatt került a franciaországi DNS-adatbázisba.

El kell ismerni, hogy napjainkban a nemzetközi bűnügyi együttmüködés a kilencvenes években még nem remélt lehetőségeket kínált az utóbb bemutatott nyomozási módszerek sikeres alkalmazására.

\footnotetext{
17 Kovács Lajos (2003): i. m. 230-244. o.

18 Bogdány Gyula: i. m. 8-9. o.
} 
Szükségesnek tartjuk kiemelni az ebben az ügyben is tapasztalt, talán a múltból eredő rossz beidegződés folyományát, a helyes büntetőjogi minősítéshez képest történő alulminősítés jelenségét. Az ügyben a nyomozás első szakaszát 1998-ban, emberölés alapeset minősítés mellett fejeztük be, emiatt a 2013-ban beállni látszó elévülés miatt 2014-ben adminisztratív okból sor került valamennyi bünjel lefoglalásának megszüntetésére, majd a tárgyakat selejtezték. A bíróság 2018-ban(!) ítéletében döntött az emberölés minősítő körülményeinek megállapítása mellett, a büncselekmény el nem évülése felől, és a bünösség kérdésében is, az élő terheltre nézve marasztalón.

Utólag nem tartjuk végzetes hibának a bünjelek időközbeni selejtezését, csupán a bizonyítást nehezítö körülménynek.

A nyomozási hiba és szerencse fogalmának összefonódását és kétarcúságát jól szemléltetik a hírhedt belgiumi sorozatgyilkos, Marc Dutroux ügyében megismert nyomozási tapasztatok. 1995-ben, az áldozatok közül két kislány fogva tartásának helyéül szolgáló ház kutatását végzö rendörök nem tudták azonosítani az egyikük által hallani vélt segélykérő hangokat, nem fedezték fel a bezárt és később, ott, emiatt elhunyt sértettek rejtekhelyét. ${ }^{19}$

A mélykúti cipész brutális megölése miatt folytatott nyomozásunkban a teljesen feldúlt lakásban a négy napig tartó szemle idején megtalált, egyetlen cigarettacsikk lett az elkövetök veszte. Az azon lévö nyál hordozta DNS-profil egyezöséget mutatott egy, két évvel korábban, Budapesten elkövetett, de felderitetlenül maradt rablás helyszinén rögzitett csikkröl származó DNSprofillal. A kerületi nyomozó kellóen rest volt ahhoz, hogy a rabláskor elvitt mobiltelefon újbóli használatáról lekért hiváslista alapján azonositsa az elkövetöt. A rabló személyét - immár az emberölés nyomozásában végzett rövid raszterezés után - az új használó ismeretségi köréböl, a Mélykúton rit$k a$ vezetékneve miatt, egyezönek találtunk azzal a személlyel, aki szerepelt azon a ,bakancslistán”, amelyet a helyszíni lábbelinyom nyomképzője azonositási vonalán szereztünk be a szomszédos kisvárosban megtartott OKJ-s tanfolyamon kiosztott bakancsokról. A fövárosi rablás után az elvitt telefon Békés megyébe került, a borsodi származású elkövetö pedig a családjával Mélykútra költözött.

19 Kovács Lajos (2003): i. m. 37-38. o. 
Vajon az egykor mulasztással terhelt nyomozás elvarratlan szálainak felvételével kiderített emberölési ügy sikerében mekkora részt képviselt a DNS-találat formájában megjelenő szerencse?

A Kecskeméten megölt cukrászlány gyilkosa évtizedeken át kisebb súlyú csalásokból élt a fơvárosban. E büncselekmények elkövetöjeként nem esett a DNS-minta-vételre kötelezettek körébe. A DNS-találatot eredményezö mintavételére rablás gyanúsitottjaként került sor, ezt a nyomozást röviddel később, büncselekmény hiányában megszüntették ellene.

\section{A felismert hibák elkerülésének beépítése a jövő gyakorlatába}

Az emberöléses ügyek nyomozásai a korábban felsorolt alanyi és tárgyi ismérveken túl azáltal válnak a közvélemény és a szakma számára emlékezetessé, hogy mikor és milyen sikerrel zárultak. Az időtényező jelentősége napjainkban egyre inkább elhalványul, hiszen - döntően a DNS-alapú azonosításnak tulajdoníthatóan - egyre nagyobb számban fordul elö az elkövetőnek a helyesen megállapított (!) elévülési időn ${ }^{20}$ belül történő felderítése. Az egykor jelentős erőfeszítéssel, de sikertelenül befejezett nyomozások egy más ügyben levett minta alapján váratlan DNS-találattal megoldódnak.

(Szerencsére ez a módszer Magyarországon - ellentétben az Egyesült Államokban zajló folyamatokkal - nem az egykor tévesen elítéltek rehabilitációjáról vált híressé.)

Ne feledjük azonban, hogy önmagában a DNS-találat fontos, de nem kizárólagos bizonyíték, hiszen az így azonosított személyt még több-kevesebb munkával „be kell húzni” az elkövető szerepébe. Védekezését, alibijét ellenőrizni, akár cáfolni, személyét időben és térben a büncselekményhez kell rendelni. Szükséges tisztázni cselekvőségét, elő- és utótevékenységét, vizsgálni kell a minősitő körülmények meglétét és elvégzeni a bizonyításukat. Ez az aprólékos vizsgálati munka kevésbé látványos, de jelentősége vitathatatlan. Sikertelensége és ennek következményeként a valódi tettes ellen a jogkövetkez-

\footnotetext{
20 1993. május 15-től nem évül el az emberölés súlyosabban minősített eseteinek a büntethetősége. A Büntető Törvénykönyvről szóló 1978. évi. IV. törvény 33. § (2) bekezdés c) pont.

http://www.njt.hu/cgi_bin/njt_doc.cgi?docid=3356.237644\#foot_28_place Hatályba léptette a büntető jogszabályok módosításáról szóló 1993. évi XVII. törvény 1. § (2) bekezdése. https://mkogy.jogtar.hu/jogszabaly?docid=99300017.TV
} 
mények elmaradása - első értékelésben - bizonyosan nyomozási hibának fog tünni, holott lehetséges, hogy valójában végzetesen nehezített volt a bizonyítás.

A cukrászlány gyilkosa csak az utolsó szó jogán ismerte be az emberölés elkövetését, a homoszexuális vasutasé pedig a teljes büntetöeljárásban tagadott.

Az említett állapotba kerülő ügyek nagy odafigyeléssel, tervszerüen, de lendületesen folytatott nyomozásokat igényelnek, amelyek bizonyítási metódusába be kell építeni mindazokat a szakmai tapasztalatokat, amelyek ügyanalógiák kapcsán sikerre vagy különböző okból bekövetkezett hibákra vezettek.

A sikeres és hibás gyakorlatok megismerése és a praxis részévé tétele feltételez egyfajta szakmai kontinuitást az egymás után következő nyomozói generációk között, és ennek révén lehetővé válik a rendszer belső hibajavítási mechanizmusának folyamatos fenntartása.

A 2000-ben eltünt bajai gyermek ügyében felismert negativumok kiküszöbölésére törekedtünk a 2014-ben eltünt szerbiai kislány ügye kapcsán, a szerb kollégákkal történt napi egyeztetések mellett, a fokozott tempóval bevezetett helyi, megyei és - a sajtó révén - országos intézkedésekkel. ${ }^{21}$

A DNS-kontaminációnak és az ebböl eredö téves nyomozási irányoknak kivántuk elejét venni 2005-ben, amikor a Mária körúti kettös emberölés tapasztalatai alapján - felismerve ennek veszélyét - a mintavételi eszközök sterilizálását és ilyetén alkalmazását irtuk elö a megyei bünügyi technikai személyzet számára.

El kell ismerni viszont, hogy a Mária körúti bünügy helyszinéröl mintaszerü, kellöen tagolt, részletes és áttekinthetö szemlejegyzökönyv készült, a bizottságvezetö késöbbi közlése szerint a hazai bünügyi technika ikonikus alakja, Vedres Mátyás, akkoriban meghonositott helyszinfeldolgozási módszere alapján.

A helyszíni nyomszennyezödés veszélyével azóta is számolunk, és a bünjeltárgyak DNS-vizsgálatánál kizárás céljából a szakértőnek megküldjük a helyszínnel bizonyithatóan vagy feltehetóen érintkezö személyek mintáit is.

A kunszállási belga házaspár ügyében folytatott nyomozás első hónapjában bebizonyosodott, hogy a férfi sértett holttestén kimutatott idegen DNS - a

21 Bogdány Gyula: Tijana Jurić eltűnési ügye. Belügyi Szemle, 2016/1., 107-116. o. 
legkörültekintőbb helyszinvédelem ellenére - a bünügyi technikusok egyikétöl származott. Ellentétben néhány kritikus vélekedéssel ${ }^{22}$, az így elöforduló nyomszennyezödést nem tartottuk hibának. A lehetséges káros következményeket felismertük és az idejében történö eliminációval számos nyomozási feladattól mentesültünk.

A kiskörösi kislány és a kiskunfélegyházi cukrászlány ügyében tapasztalt passziv kihallgatói magatartást kerültük a kiskunfélegyházi homoszexuális vasutas ügyében, amikor fenntartva a vallomástételi kapcsolatot a gyanúsitottat a nyomozás szakában tíz alkalommal hallgattuk ki, abból az ismert elvböl kiindulva, hogy a valótlan tartalmú vallomás is értékesebb a nyomozó számára, mint a semmilyen. Ebben az ügyben, a gyanúsitott által elfoglalt védekezés a biróság által lefolytatott bizonyitásban hiteltelennek bizonyult és elmarasztaláshoz vezetett.

2016-ban, Kecskeméten, egy társasházi bérleményben, egy prostituált megölése nyomozásának kezdetén - alkalmazva a hasonló ismérvekkel történö fövárosi emberölések felderitési tapasztalatait - kiemelt jelentöséget tulajdonitottunk a sértett mobiltelefonjából megszerezhetó adatoknak, és az utolsó vendég személyének. Elképzelésünk nyomán órákon belül azonositottuk és elfogtuk a tettest. ${ }^{23}$

E sorok írójának alkalma volt részt venni egy nemzetközi ásványolaj-forgalmazó vállalat képzési napján, amelyet az üzemanyagtöltő állomások személyzetének rendeztek a munkájukat fenyegető biztonsági kockázatok felismerése, csökkentése és az esetlegesen megvalósult támadások hatásainak mérséklése céljából. Levetítettek egy oktatófilmet, amelyben a büntetésüket letöltött egykori benzinkúti rablók mondták el, hogy milyen szempontok alapján választották ki a célpontjaikat, hogyan készültek a végrehajtásra, a menekülésre, az azonosításuk elkerülésére. A látottak erős hatást váltottak ki a munkavállalókból, és bizonyosan hozzájárult a magatartásuk változásához.

22 Az életelleni büncselekmények nyomozásának aktuális kérdései. ORFK, 2017. Az értékelés $A$ hely szinen végzett tevékenységgel összefüggésben az eredményességet befolyásoló tényezök címủ pontjában - álláspontunk szerint kellő indokoltság nélkül és felületesen értékelve - helyszínen elkövetett hibaként nevesítette az esetet.

23 Bogdány Gyula: A prostituáltak sérelmére elkövetett emberölések és nyomozásuk néhány sajátossága. Belügyi Szemle, 2018/5., 142-144. o. 
Az emberölési ügyekben felháborító és kegyeletsértő lenne ilyen jellegü oktatóanyagot készíteni. Az alacsony esetszám okán nem is a lehetséges sértetteknek kell felismerniük az életükre leselkedő veszélyeket, hanem a megvalósult esetek kinyomozására szakosodott bünüldözők számára kínálnak információt az egyes elkövetők beszámolói a tettükről.

Ha valahol, hát a büntetőjogi felelösség elbírálásának színterén, a bírósági tárgyalótermekben bizonyosan elhangzanak a terheltek szájából olyan nyilatkozatok, amelyeket a vád ellenében (beismerés esetén azzal lényegében nem szembehelyezkedve), a terhükre rótt cselekménnyel összefüggésben kénytelenek megtenni.

A bírósági tárgyaláson elhangzottak és az ítéletek indokolása olyan értékméröi a nyomozásoknak, amiknél hitelesebb aligha található. Véleményünk szerint akár a váddal egyező, akár attól eltérő tényállással, akár elmarasztalással, akár felmentéssel végződő ítélettel lezárt büntetőeljárások bírósági tapasztalatai méltatlanul és könnyelmủen maradnak ki a rendőrség hibajavítási eszköztárából.

\section{Központi törekvések a hibák elkerülésére}

A felsorolt példák kapcsán adódik a kérdés, hogy ha a nyomozó hatóság felismeri a tevékenysége gyengeségeit, esetleg már a nyomozások menetében miért nem tesz kellő hatékonyságú megelőző intézkedéseket ezek elkerülésére, esetleg minimalizálására.

A korábban folyamatosan csökkenő, majd jelenleg az évi száz körüli esetszámban $^{24}$ megálló és megközelítőleg kilencvenszázalékos eredményességgel felderített, szándékos, befejezett emberölések nyomozásainak - álláspontunk szerint - három szakaszában kaphat nagyobb szerepet a nyomozó hatóság önrevíziós mechanizmusa. A folyamatban lévő nyomozásokban az esetleges hibák nagyobb arányú és természetszerüleg mielőbbi elkerülésében, az ismeretlen tettes miatt lezárt nyomozások ügyeinek utólagos felderítésében, valamint a vádemelésre átadás után bizonyítottság hiányában ügyészi szakban megszüntetett vagy bírói szakban felmentéssel zárult ügyek vonatkozásában.

Ne feledkezzünk meg azonban a gyanús eltünések és a rendkívüli halálesetek mögött megbúvó életelleni büncselekmények csoportjáról sem. Ezek az ügytípusok nem szerepelnek a bünügyi statisztikában és a közérdeklődés

24 https://bsr.bm.hu/ 
fókuszában. Noha a feltárásukra szolgáló közigazgatási hatósági eljárások magukban foglalják a látencia bizonyos lehetöségét, a céljuk mégiscsak a deliktum felfedése. A felderítés garanciáját csak a szakmai igényesség és a lelkiismeretes hozzáállás jelenti, amely egyéni kompetenciák függvénye.

Az Országos Rendőr-főkapitányság időről időre áttekinti az élet elleni büncselekmények, azon belül az emberölések helyzetét, az esetek mennyiségi mutatóiban, az elkövetési sajátosságokban, gyakoriságában, előfordulásában történt változásokat, valamint a nyomozások eredményességét befolyásoló tényezőket. Az elemzések számba veszik a felderítetlenség okait, keresik a sikeresebb megoldásokat és a hibák csökkentésének lehetőségeit.

Az Országos Rendőr-főkapitányság részéről 2010-ben, egyebek közt az ügytípus helyszíni szemléi színvonalának emelése érdekében önálló státusú szemlebizottság-vezető munkakör létesítésének, valamint a területi szervektől az érintett állománynak tapasztalatszerzés céljából a Budapesti Rendör-fökapitánysághoz történő delegálása vetődött fel javaslatként. ${ }^{25} \mathrm{~A}$ megyei szerveknél az esetszámok előre nem jelezhető változásai, valamint szervezeti és önállósági kérdések miatt a javaslatok általában nem találtak befogadásra.

2011-ben, merőben új koncepció alapján, a szakirányítás erőteljes támogató, de nem nyomásgyakorló szerepvállalásának hirdetésével hosszú távú elképzelések fogalmazódtak meg. ${ }^{26}$ A központi szerv a szakirányítói tevékenysége céljaként határozta meg az adott egyedi esetnek a tágabb (országos) összefüggésbe helyezését, a nyomozást végrehajtó előtt nem ismert lehetséges összefüggések feltárását, a korábbi tapasztalatok megfogalmazását, öszszességében a nyomozás támogatását olyan információkkal, amelyek a végrehajtónál nem állnak rendelkezésre, vagy azokhoz nem fér hozzá.

Az emberölési ügyek kezdeti, kritikus szakaszára nézve - nézetünk szerint - máig hátrányosan ható, ezért felelőtlen és elhibázott döntéssel felszámolt bünügyi orvosi hálózat újbóli felépítésének szándéka mellett a jelentés kitért a bírói szakban felmentéssel záruló eljárásokban a bizonyítást befolyásoló, az eljárás kimenetelét meghatározó hibák, hiányosságok megismertetésének vállalására is.

A jelentés leszögezte, azáltal, hogy a területi nyomozó hatóságok érintettek mind a folyamatos büntetőeljárások, mind az utófelderítés kapcsán, felelősségük jelentős az eltünéses akták felülvizsgálatánál, mindennapi tevé-

25 ,A 2009-ben megszüntetett vagy felfüggesztett emberölések miatt folytatott büntetőeljárások felülvizsgálatáról” ORFK, 2010.

26 „A felderítetlen emberölések aktuális kérdéseinek helyzetértékelése, a szakirányítás feladata az utólagos felderítések elősegítésére” ORFK, 2011. 
kenységük színvonalának minősége gyakorolja a legközvetlenebb, legmeghatározóbb hatást a felderítetlen emberölésekre és az utófelderítéssel érintett ügyekre. Ezért a központi bünügyi szakirányító szervnek a nyomozások menet közbeni áttekintésével, a bünügyi elemző-értékelő főosztálynak az elemzö-értékelő tevékenység nyomozástámogató szerepének kiterjesztésével, a Nemzeti Nyomozó Irodának ${ }^{27}$ a felderítetlen (különösen az elévüléshez közelítő) ügyek és kiemelt eltünések monitorozásával támogatnia kell a területi szervek emberölési ügyekben kifejtett tevékenységét, miközben nem csorbulhat e szervek önálló felelőssége a bünügyi munka ellátásában.

A jelentés újszerü módon a következő kritikus felismerést tette a hibajavítás nehezítettségéröl: „Általános tapasztalat, hogy minden jóindulat mellett sem könnyü saját magunkkal szemben elfogulatlannak lenni. Egy emberöléses ügyben sem az ügyfeldolgozás, sem a felülvizsgálat fázisában nem játszhatnak szerepet gyarló emberi tulajdonságok, kizárólag annak van jelentösége, hogy korábbi hibáink okán azokat a késöbbiekben ne kövessük el, és példánkon okulva más se kövesse el őket. Jobb elöbb szembesülnünk hibáinkkal, mint késöbb ráébredni azok következményeinek visszafordithatatlan voltára."

A szakirányítói jelentés elismerte azt, hogy az emberöléses ügyekben a nyomozását végzők speciális szaktudása elengedhetetlen feltétele a sikernek. Ezt a tudást az egyébként nem nélkülözhető intézményes rendőrképzésen és szakmai gyakorlaton túl szakirányú belső képzésekkel kell hozzáférhetővé tenni és elmélyíteni a létszámában és összetételében stabilizált bünügyi állomány számára.

A 2011-es jelentés szakmai célkitüzései nagymértékben megvalósultak. A kiemelt ügyeket felderítö főosztály teljesíti küldetését az utófelderítések és gyanús eltünések vizsgálatával, valamint a genetikai szakértői tevékenység fejlesztési irányainak nyomatékos felhasználói megfogalmazásával. Az elemző-értékelő munka ${ }^{28}$ jelentőségét felértékelte az elektronikus adat mint a büntetőeljárási törvényben is nevesített bizonyítási eszköz ${ }^{29}$ tömeges megjelenése. Évtizedes szünet után rendszeressé váltak az életvédelmi nyomozók éves továbbképzései.

\footnotetext{
27 A Nemzeti Nyomozó Iroda itt meghatározott feladatkörét 2013. január 1-jétöl az ORFK bűnügyi föigazgatójának közvetlen irányítása alatt álló, területi besorolású, főosztály jogállású szervezeti elem, a kiemelt életellenes ügyeket felderítő főosztály vette át, amely 2016. február 1-jétỏl kiemelt ügyeket felderítő főosztály névváltozással a Készenléti Rendőrség szervezetébe tagozódott.

28 22/2017. (VI. 22.) ORFK utasítás, a forrónyomos tevékenység egységes végrehajtásáról. A 7/e) pont a forrónyomos csoport tagjai között nevesíti az elemzö-értékelő munkatársat. https://net.jogtar.hu/jogszabaly?docid=A17U0022.ORF\&timeshift=fffffff 4 \&txtreferer=00000001.TXT

29 A büntetőeljárásról szóló 2017. évi XC. törvény (Be.) 165. § f) pont; 205. § (1)-(2) bek. https://net.jogtar.hu/jogszabaly?docid=A1700090.TV\&timeshift=fffffff 4 txtreferer=00000001.TXT
} 
A meghatározott irányok szerint előrehaladó fejlesztések megteremtették az emberölések sikeresebb nyomozásának feltételeit, a folyamatban lévőkét és az utólagosan felderítettekét egyaránt. A digitális adatok rutinszerú és hatékony felhasználásán túl korszakos jelentőséggel bírt a poligráfos vizsgálat eredményességének elismerése és alkalmazásának szintén a büntetőeljárási törvényben, bizonyítási cselekményként ${ }^{30}$ történő szabályozása.

Az élet elleni bủncselekmények nyomozásainak legutóbbi, 2017-es helyzetértékelése azonnali beavatkozást igénylö, rendszerszintü problémák hiányában a szakértés terén a mintavételi protokoll és a megőrzési lánc nem újszerü fontosságát hangsúlyozva és az utófelderítések lehetőségének kutatásában határozott meg feladatokat.

A 2010-től 2017 első fél évéig terjedő időszakban - döntően az ismétlődő daktiloszkópiai és genetikai szakértői vizsgálatok eredményeként - országosan huszonöt emberölési ügyet derítettek fel utólagosan a nyomozó szervek. ${ }^{31}$ Ebből a mennyiségből Bács-Kiskun megye három üggyel vette ki a részét, ez röviddel később ötre emelkedett.

\section{Szervezeti hibaforrások és a kiküszöbölésük lehetőségei}

Ha ilyen kedvező folyamatok zajlanak az emberölések nyomozásai terén, akkor mi adja a jelen tanulmány alapját, aktualitását?

Álláspontunk szerint ameddig egyetlen emberölési ügy is felderítetlenül maradt a múltból vagy keletkezik a jövőben, különösen, ha a kudarc a nyomozó hatóság hibáira vezethető vissza, indokolt a téma napirenden tartása.

Utóbbi alapvetésből kiindulva a következő meghatározó tényezőket tartjuk szükségesnek kiemelni, mint amelyek a nyomozási tapasztalatok rétegesen rendezett és a gyakorlatba ágyazott felhasználása ellen hatnak.

Egyrészröl, többször hangsúlyozott tény, hogy az emberölési ügyek nyomozásai - annak ellenére, hogy esetszámuk szinte nem mérhető az összbűnözésen belül - minden tekintetben, így jogi, kriminalisztikai, kommunikációs, szervezeti, politikai és megannyi más vonatkozásban, kitüntetett helyet foglalnak el a bünüldözés teljes spektrumában. A koncentrált figyelem nemcsak az egyes ügyek alakulására irányul, hanem a munkájukat végző specialistákra is. Ennek

30 Be. 206. $\S ; 212 . \S(1)-(2)$ bek

$31 \mathrm{Az}$ életelleni büncselekmények... i. m. 
a kívánalomnak csakis kimagaslóan képzett, jól kiválasztott, kellő szakmai gyakorlattal és tapasztalattal felvértezett tagokból álló egység felelhet meg.

Példának okáért, nem fogadható el, hogy emberölés nyomozásának (hasonlóan a kezdő bizottságvezetőnél írtakhoz) tiszthelyettes előadója legyen, ugyanis e bonyolult szakmai tevékenységhez szükséges néhány jogi és kriminalisztikai szemeszter elvégzése.

Nem lehetséges az ezeknek a speciális követelményeknek megfelelő személyeket egyszerü áthelyezéssel, csupán elméleti kiképzéssel biztosítani. Ez esetben a szakember-utánpótlás körültekintő és felelősségteljes feladat. Az emberölésben nyomozó szakember, ideértve a nyomozás irányítóját, minden ízében (látásmódjában, felkészültségében, képességeiben) képzett és feladatára érett kriminalista kell, hogy legyen ${ }^{32}$ Személye lehet az egyik garanciája a szakmai tapasztalatok beépítésének és azok értő felhasználásának.

Sajnos a leírt ideális szakembertípus nehezen formálódik azzá, mert a rendőrség szervezetére is jellemző gyors személyzeti mozgás könnyen elsodorja szakterületéről. A helyére érkező pedig ismét kezdő a specializációban. ${ }^{33}$

Az emberölési nyomozások hatékonyságnövelése kapcsán szükségesnek tartjuk kiemelni a vezetői felelősség kérdését is.

Nem kétséges, hogy a súlyos élet elleni büncselekmények nyomozásai különleges atmoszférát teremtenek mind a szervezeten belül, mind azon kívül. Ilyen felfokozott helyzetben kívánatos, hogy a nyomozó szerv vezetője a koncepcióját egyebek közt a vezetői szintek, a nyomozási struktúra, erőforrások meghatározása, belső és külső kommunikáció, együttműködés rendje, innováció becsatornázása alapján építse fel. Elképzeléseit befolyásolhatják a nyomozás során adódó bizonyos krízishelyzetek is (például nyomozási holtpontok, újabb esemény, szervezési, vezetési koncepcionális hibák, médiahatás).

A vezetőnek a szakmai munka zavartalansága érdekében külső befolyásolásmentességet kell teremtenie az általa irányított szervezeten belül a nyomozást irányító élcsapat (elvártan a területi szervek bünügyi osztályvezetője és a közvetlen stábja, vagyis az osztály nyomozói) számára. Ennek része, hogy begyüjti az impulzusokat és csak a relevánsakat adja tovább a nyomozás részvevőinek, a többit a jelentéstételhez, koordinációhoz használja fel.

$\mathrm{Az}$ éreztetett felső vezetői nyomás nyomozói csőlátáshoz vezet, ezért a vezetőnek olyan vezetési módszereket kell alkalmaznia, amelyek a nyomo-

\footnotetext{
32 Dobos János: Ars criminalistica. In: Kovács Gyula (szerk.): Dobos-könyv. Emlékkönyv Dr. Dobos János születésének 80. évfordulója tiszteletére. Patrocinium Kiadó, Budapest, 2015, 24-35. o.

33 Kovács Lajos (2003): i. m. 139-140., a negatív vezetői tulajdonságokról 145-146. o.
} 
zókat minél nyitottabb, kreatívabb gondolkodásra sarkallják. Csatornát kell teremteni továbbá a kriminalisztikai innovációk kinyilatkoztatására. ${ }^{34}$

Nem megfelelő vezetői magatartás esetén a legsúlyosabb defektusokat a kezdeti időszakban szenvedheti el az ismeretlen vagy akár ismert személyü gyilkos ellen indult nyomozás.

A megnövekedett szakmai, lelki, média- és fizikai terhelés mellett (ne feledjük a kialvatlanságot) a sürgető és nem támogató vezetői elvárások közepette, egyebek közt ilyenkor válnak az ellenőrizendő személyek célszemélylyé, rosszabb esetben gyanúsítottá35, osztódnak meg energiák nem célirányos, tömeges adatkérések, ellenőrzések elrendelése miatt.

Növeli az önállótlanságot és bizonytalanságot okoz a nyomozásban részt vevők körében, ezért káros gyakorlatnak tartjuk, ha a vezető - mint kifejtettük - meghatározóan speciális tudást és ismereteket igénylő helyzetben, emberölés nyomozásában a saját - egykori bünügyi gyakorlatából táplálkozó, esetleg azt nélkülöző - verziója szerint közvetlen, az addigi szakmai koncepciótól eltérő szakmai vagy annak tünő utasításokat ad. A vezető és irányító szerepek zavara észlelhető e vezetői magatartás esetén, amely külsőleg az irányítói jogkör időszakos magához vonásában, egyszersmind a felelősség hárításában nyilvánul meg.

Más esetben találkoztunk olyan következetlen és a szellemi tőkét pazarló vezetői magatartással, amikor a megyei bünügyi osztályvezető a képzett életvédelmi nyomozóit látszólagos eseménymentes időszakban közterületi járörözésre küldte, miközben az irattárban sorakoztak a felderítetlen emberölési ügyek.

Az emberölések kapcsán keletkezett, személyekhez, nyomozócsoportokhoz kötődő tapasztalatok a természetes elvándorlás, a nyomozói generációváltások miatt szóródnak, a tudás nem koncentrálódik a szervezetben. A negatív hatást erősíti egy további szóródási vetület, amely a szervezeti széttagoltság és az átszervezések talaján keletkezik.

A fővárosi és a megyei rendőr-főkkapitányságok bünügyi szervei mellett, országos hatáskörrel, a Készenléti Rendőrség Nemzeti Nyomozó Iroda és a Készenléti Rendőrség kiemelt ügyeket felderítő főosztálya végez emberölé-

\footnotetext{
34 Krajnyák Péter: A sorozat-emberölések nyomozásának speciális kérdései. Diplomamunka. Nemzeti Közszolgálati Egyetem Rendészettudományi Kar, Budapest, 2014

35 A nyomozás során adódó kritikus helyzetben tanúsított támogató vezetői magatartás csak segítheti a nyomozás irányítóját a helyes döntés meghozatalában. Erre példát szolgáltat egy bajai jogeset. Lásd Bogdány Gyula: Forrónyomon üldözés élet elleni büncselekmény nyomozásában. Belügyi Szemle, 2014/4., 98-111. o.
} 
sek ügyében nyomozásokat. Az említett nyomozó szervek müködésüknél fogva természetesen szakfeladatként kezelik a munkájukat, de az önálló müködés azt is előidézi, hogy a keletkezett nyomozási tapasztalatok bizonyos mértékben elszigetelődnek, megmaradnak az egység kollektív emlékezetében, hagyományaiban, módszer- és eszköztárában. Különösen a Készenléti Rendőrséghez tartozó szervezeti elemek időnként átszervezésen esnek át (bár ez súlyosabb hatást kiváltva megtörténik a megyei rendőr-fökapitányságokon is), e változásokkor pedig nagy eséllyel elvész az addigi közös tapasztalat.

A megyei rendőr-főkapitányságok többségében kialakult szakmai mühelyek ${ }^{36}$ eredményességének előfeltétele a stabil és támogató vezetés által biztosított, jól funkcionáló és profiltiszta szervezeti keretek között, alkotó módon tevékenykedö, állandósult összetételü, tapasztalt bünügyi nyomozók alkotta egységek megléte. Az egység nívójának elismerése egyebek között lemérhető az ügyészséggel való együttmüködésben és az ügyészség által vádemelésre vitt ügyek sikerében is.

Némely, kisebb ügyforgalmú megyei nyomozó szerv esetén az új ismeretekkel, tapasztalatokkal való felvérteződést késlelteti az esetek ritkább bekövetkezése.

A tapasztalatok megosztását és az ebből következő menet közbeni hibajavítás képességét hasznosan szolgálják a központi szerv által évente szervezett kétnapos továbbképzési kurzusok. Értékelésünk szerint kimutatható az igény arra, hogy e képzéseket az érintett életvédelmi nyomozói állomány (országosan nagyjából háromszáz fö ${ }^{37}$ ) egészét lefedő, tanfolyami jellegü képzéssé fejlesszék.

Hiányolhatók azok a szakmai kiadványok, amelyek bizonyos különleges jogesetek feldolgozását tüzték ki célul. A magyar rendőrségnél egykor olyan belső terjesztésủ időszakos kiadványok, tájékoztatók ${ }^{38}$ kerültek a szakmai közönség elé, amik nemcsak az egyes büncselekménytípusok elleni sikeres fellépéshez adtak metodikai támogatást, de az emberölési ügyek kritikus tárgya-

\footnotetext{
36 Például a Békés Megyei Rendőr-fökapitányságon: https://www.beol.hu/kek-hirek/helyi-kek-hirek/amezokeres-a-vadaszboltos-gyilkossagnal-sem-adtak-fel-1595684/ vagy a Győr-Moson-Sopron Megyei Rendőr-fökapitányságon: https://www.hirado.hu/2017/01/17/husz-percen-at-nezte-mielott-megfojtotta-a-sebesult-esztert/

37 Dr. Szokolai Zoltán rendőr alezredes, az ORFK bünügyi főosztálya bünügyi osztályvezetőjének közlése. Bünügyi és vizsgálati osztályvezetők éves továbbképzése, Csopak, 2017.

38 Például az 1950-1960-as években: Bünügyi Technikai Tájékoztató és Bünügyi Tájékoztató BM Országos Rendőrkapitányság, majd a BM II/I. Csoportfőnökség kiadványai; Realizált bünügyek sorozat a BM Tanulmányi és Módszertani Osztály kiadványa; Tájékoztató az 1972-1992 években ismeretlen tettes által elkövetett emberölésekröl. ORFK Bünüldözési Osztály, 1993.
} 
lásával vagy akár csak ismertetésével is elősegítették a későbbiekben alkalmazott nyomozási módszerek eredményességét.

Napjainkban az olvasó által kézben tartott periodika lángőrzőként látja el ezt a szerepet, annak ellenére, hogy küldetésében a tárgyalt szakterületnél jóval szélesebb tudományterületek szolgálatára vállalkozott. ${ }^{39}$

\section{Összegzés}

Tekintve a deliktum súlyát, ritkaságát és az eredményes megoldásukhoz füzödő, döntően a szervezeti csatornákon keresztül ható társadalmi elvárást, az emberölési ügyek rosszul türik a jogalkalmazók által a büntetőeljárás során elkövetett hibákat. A hibák többes előfordulása és különösen a kriminalisztikai eredetüek akár végzetesen befolyásolhatják az ügy befejezését, a büntetőjogi felelősség elbírálását. A hibaforrások feltárása és a szakszemélyzettel történő megismertetése elsősorban a rendőrség mint az ügytípusban nyomozó hatóságként eljáró szervezet feladata. A hibák újratermelődésének jelensége felveti egy bünügyi protokoll kidolgozásának és bevezetésének szükségességét, amely természetesen nem lehet mentes az informatikai megoldásoktól. Ennél hatékonyabbnak tartjuk - természetesen a számonkérhetőség mellett - a folyamatos terhelés alatt, hosszú távon müködő, stabil egységek számára a nyugodt szakmai alkotómunka feltételeinek megteremtését.

A tulajdon és az élet védelme minden korban alapvető társadalmi érdek, sérelmük üldözendő tett volt, ezért az élet elleni cselekményeknek a jövőben sem várható csökkenő mértékủ megítélése. A gyorsuló technikai fejlődés vívmányai visszafordíthatatlanul szorítják háttérbe a személyes képességeken alapuló problémamegoldást. A bünfelelősség feltárása a jövőben várhatóan egyre inkább sémák, majdhogynem automatizmusok alapján történik.

Álláspontunk szerint azonban az életvédelmi nyomozói szakterület más bűnügyi szaktevékenységtől történő megkülönböztetésének és elismerésének nagyobb nyomatékkal kell ebben a folyamatban latba esnie, hiszen a gyilkossági nyomozó intuitív gondolkodásának nemcsak a szokványos bünözők, ha-

\footnotetext{
39 Példaként említhetők a romagyilkosság-sorozatként elhíresült büncselekmény önkritikus elemzései. Lásd Bócz Endre: Az úgynevezett „romagyilkosságok” ügyének néhány tanulsága. Belügyi Szemle, 2017/7-8., 5-37. o.; Petőfi Attila: A 2008-2009-es romagyilkosság-sorozat nyomozása. Belügyi Szemle, 2017/7-8., 38-55. o.; továbbá az Izsáki Rendőrőrsön, 2013-ban, rendőrök által elkövetett halált okozó testi sértés ügyének bemutatása: Bezerédi Imre: Esetelemzés. Belügyi Szemle, 2016/11., 108-116. o.
} 
nem a büntetőjogi felelősségre vonással addig nem találkozó elkövetők gondolatvilágának megértésére is kell irányulnia.

Éppen ezért egyelöre csak fantáziánk képes körvonalazni azt a víziót, amelyben az emberölés helyszínére vonuló nyomozó (és a felettesei!) számítógépének képernyőjén, a rendelkezésre álló adatok alapján (már ez is viszonylagos, az ügyről befutó információk folyamatos bővülése miatt), az öszszes számításba vett verzió közül a legvalószínübb ikonja villog és mintegy a célt befogva ad jelet a megfelelő nyomozási cselekmények automatikus megindítására - szerencsés esetben, hiba nélkül! ${ }^{40}$

40 Bogdány Gyula: Önakasztásnak álcázott emberölés felderítése rendőri vezetői szempontból. Zárógondolatok. Diplomamunka. Nemzeti Közszolgálati Egyetem Rendészettudományi Kar, Budapest, 2014, 96. o. 